Article

\title{
Exploring the Application of Lean Best Practices in Remanufacturing: Empirical Insights into the Benefits and Barriers
}

\author{
Elzbieta Pawlik $^{1, *}$, Winifred Ijomah ${ }^{1}$, Jonathan Corney ${ }^{2} \mathbb{D}$ and Daryl Powell ${ }^{3}$ \\ 1 Department of Design, Manufacture and Engineering Management, University of Strathclyde, \\ Glasgow G1 1XJ, UK; w.l.ijomah@strath.ac.uk \\ 2 School of Engineering, University of Edinburgh, Edinburgh EH9 3JL, UK; J.R.Corney@ed.ac.uk \\ 3 Department of Industrial Economics and Technology Management, Norwegian University of Science \\ and Technology, NO-7034 Trondheim, Norway; Daryl.J.Powell@ntnu.no \\ * Correspondence: pawlik.elzbieta@gmail.com
}

check for updates

Citation: Pawlik, E.; Ijomah, W.; Corney, J.; Powell, D. Exploring the Application of Lean Best Practices in Remanufacturing: Empirical Insights into the Benefits and Barriers.

Sustainability 2022, 14, 149. https:// doi.org/10.3390/su14010149

Academic Editor: Paulo Peças

Received: 10 August 2021

Accepted: 21 December 2021

Published: 23 December 2021

Publisher's Note: MDPI stays neutral with regard to jurisdictional claims in published maps and institutional affiliations.

Copyright: (c) 2021 by the authors. Licensee MDPI, Basel, Switzerland. This article is an open access article distributed under the terms and conditions of the Creative Commons Attribution (CC BY) license (https:// creativecommons.org/licenses/by/ $4.0 /)$.

\begin{abstract}
Remanufacturing processes have been widely identified as being important elements of a sustainable economy. However, the commercial viability of this product recovery route is significantly influenced by several operational challenges that are different from those that occur in conventional manufacturing. One of the most widely used systematic process improvement methods in conventional manufacturing is lean production, which seeks to minimize all forms of waste throughout an operation. As the academic study of lean best practices in remanufacturing processes is relatively new, there is a lack of knowledge regarding implementation and impact. As such, this paper presents multiple case studies investigating the application of lean methods in industrial remanufacturing operations. These studies focus on the automotive industry, where both conventional and remanufacturing operations have been the leading adopters of lean thinking and practice. The results of the investigation identify specific lean methods that help manage the inherent complexity of the remanufacturing processes, and consequently improve the overall productivity of the process. Similarly, factors that limit the application of lean practices within remanufacturing are also identified and discussed. Matrices for opportunities and threats are developed to enable the simple adoption of these findings. Overall, the research provides a more holistic understanding of the application of lean within a remanufacturing environment, with benefits for both academia and industry.
\end{abstract}

Keywords: remanufacturing; lean manufacturing; lean remanufacturing; circular economy

\section{Introduction}

The continued strain on the planet's resources, including limited sites for product disposal and the introduction of new environmental legislation, have resulted in a growing interest in the idea of a circular economy (CE) as a way of "harmonizing ambitions for economic growth and environmental protection" [1]. A CE maximizes material and product recovery options to reduce environmental impact and resource consumption. However, to be sustainable, a CE must also be economically viable, with productive and profitable commercial activities. With a view to sustainability in general and the triple bottom line (people, planet, profit) in particular, CE initiatives should also positively impact the social dimension.

Remanufacturing is both a CE strategy and an industrial product recovery process that shows great signs of promise with respect to economic, environmental and social impact. It restores end-of-life products to their original, as-new condition-with quality, performance and warranty equivalent to the original product [2]. Compared to the conventional manufacturing process, remanufacturing is more sustainable because remanufactured products are produced with significantly lower energy and material consumption [3]. Lund has 
highlighted that a remanufactured product requires around 20-25\% of the energy used in its initial form [4]. Taking under consideration other elements of sustainability than the environment, the remanufactured products are priced in the range of $40 \%$ and $80 \%$ of a new product, which also makes them economically favorable for the customers. In this respect, Loon and Wassenhove [5] developed a tool that can help to quickly evaluate whether remanufacturing is economically and environmentally competitive compared to producing new components. Nasr [6] has highlighted that remanufacturing meets the sustainable goals by reducing material consumption, extending the product life cycle and closing the loop on material flow. Moreover, Ijomah [7] emphasized that remanufacturing combines profitability and sustainable development as it reduces the amount of waste sent to the landfill as well as limiting the usage of virgin material, energy and labor required in the production process.

To realize a CE and ensure maximum impact on the triple bottom line, 'design for remanufacturing' must become an integral part of the product development process. Both the product concept level and the detailed product and manufacturing engineering level should be considered [8]. Moreover, several studies have also shown that design for remanufacturing might have a positive impact on reducing the cost of disassembly, refurbishment and assembly and, as a result, increase the productivity and profitability of the remanufacturing process $[5,9]$. However, design for remanufacturing often affects the production costs through the introduction of easy, yet costly, remanufacturing solutions. This investment will not be profitable if only a small percentage of the total production volume will be remanufactured [5].

Although remanufacturing creates economic, environmental and social opportunities, the process is more complex than traditional manufacturing, and researchers have identified a number of 'complicating characteristics' that make production planning and control (PPC) more difficult in remanufacturing environments (e.g., $[10,11])$. For example, the degree of automation is usually lower, and the amount of manual work higher, in remanufacturing than in conventional manufacturing [12]. This negatively impacts remanufacturing's operational performance and profitability. Remanufacturing costs should be at least lower than the production cost of new products because customers are not likely to pay more for a remanufactured product than a new one [5]. This might be the effect of public perception of the quality of remanufactured products. According to some, 'remanufactured' is just another word for 'second best' [13].

However, these problems are not regarded as insurmountable, and scholars such as Lundmark [14] have emphasized the need for industrial research to address remanufacturing challenges. One avenue of research, proposed by both Seitz and Peattie [15] and Kucner [16], is that the application of Lean Manufacturing principles might provide a solution to these challenges. Although there are reports of lean methods being adopted by commercial remanufacturers around the world, there have been few academic investigations to establish the details of how lean best practices have been applied in the context of remanufacturing operations. Consequently, both the manner of their implementation and their effectiveness is unclear and undocumented.

This paper addresses this gap by investigating how lean best practices have been implemented in remanufacturing operations to overcome the particular challenges of the industry. In other words, although the factors that limit the application of lean practices within conventional manufacturing have already been widely reported in the literature, the aim of this work is to explicitly identify the characteristics of remanufacturing that either mitigate or complicate the adoption of lean practices. This aim is associated with the following objectives:

(1) Document the application of lean best practices in remanufacturing facilities through direct case study observations and interviews

(2) Analyze the information obtained to answer the following research questions:

- RQ1: How does the application of lean best practices reduce the impact of the complexity of production planning and control in the remanufacturing processes? 
- RQ2: How does the complexity of the remanufacturing process limit the application of lean best practices?

The paper is structured as follows: first, we present a generic remanufacturing process and identify its complicating characteristics. Then, we present lean manufacturing and discuss its application to remanufacturing before describing our research design, which investigates how lean tools have been applied within the remanufacturing operations of four automotive companies. Finally, we analyze our findings and explicitly identify lean best practices as either appropriate or inappropriate for remanufacturing. We also present avenues for further research.

\section{The Industrial Remanufacturing Process}

Figure 1 shows a generic remanufacturing process. Because each specific remanufacturing process is determined by the nature of the product concerned (e.g., gearbox, valve, pump, mobile phone, etc.) it is possible that operations may occur in different sequences or be absent [17].

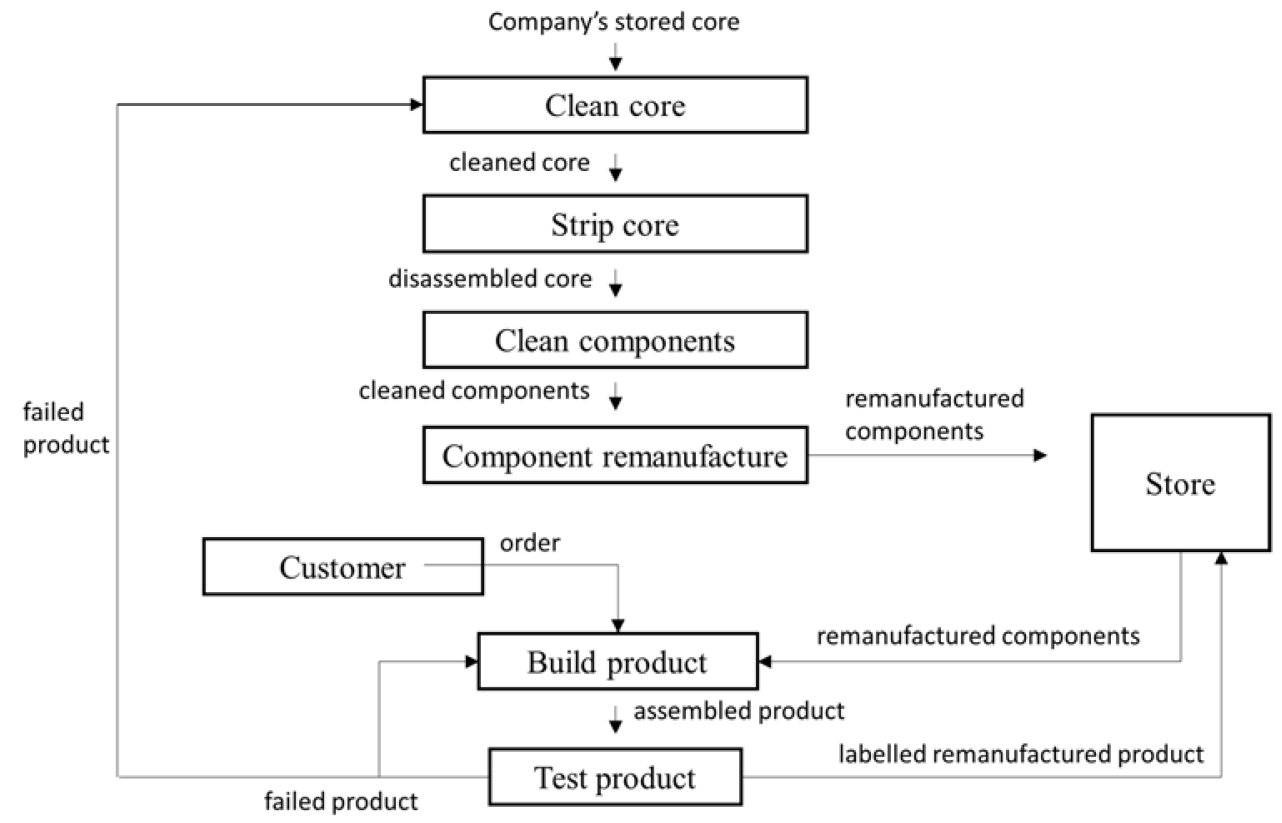

Figure 1. Generic remanufacturing process chart [2].

Typically, a remanufacturing process commences with the cleaning of the incoming products (cores). This initial cleaning is motivated by the fact that cores are often dirty, making their identification and assessment difficult $[2,18]$. Each core is disassembled and each component isolated. The individual components are further cleaned to simplify investigation of their condition. Depending on the quality and value of the components, individual parts are triaged for remanufacturing or rejected from the process. Remanufacturing of individual components comprises a range of activities required to bring worn parts back to at least the original OEM specification. When all components required for product completion are available (remanufactured or otherwise), an assembly kit is created and the product reassembled. The reassembled product is then functionally tested to ensure that its performance is at least equal to a newly manufactured, equivalent product [2]. For certain products, the remanufacturing process also provides an option for upgrade by incorporating small changes to the original design [2].

\section{Remanufacturing Challenges}

The challenges faced by remanufacturers differ significantly from conventional manufacturing and have been documented by Guide Jr. [11], who identifies the characteristics that 
complicate PPC activities within a remanufacturing process. Guide Jr.'s work is used in this research to define its scope by limiting it to the following 'complicating characteristics' that directly relate to PPC activities (see [11] for a detailed descriptions of these characteristics):

- Uncertainty in the disassembly of cores;

- Uncertainty in materials recovered from returned items;

- Stochastic routings for materials and significantly variable processing times;

- Complications associated with material matching restrictions;

- Uncertain timing and quantity of returns;

- Need to balance returns with demands;

- $\quad$ The requirement for a reverse logistics network.

\section{Lean Manufacturing}

Lean manufacturing emerged following studies of the Toyota Production System (TPS) and has since been adopted as an approach to operational excellence by many (conventional) manufacturing firms. However, Womack and Jones [19] suggest that lean thinking and practice can realize benefits in other sectors, hence, the implementation of lean best practices may be an effective way to improve the productivity and profitability of remanufacturing companies $[15,16]$.

Cut to the core, lean is about creating and delivering the most value for the customer while minimizing waste. Lean manufacturing aims to increase company productivity and product quality whilst simultaneously reducing lead-times and production costs. This is often achieved by implementing lean manufacturing 'best practices' such as 5S, Kanban, standard work, single minute exchange of dies (SMED) and Kaizen. Since lean best practices are already described extensively in the literature, they are only briefly summarized here (for further descriptions see for example [15]).

Though environmental performance is often not presented as the primary focus of lean production, 'lean and green' approaches are gaining more and more interest in recent years. The integration of lean- and green thinking can offer a means of both waste and pollution reduction, as well as the reduction in energy consumption and emissions which will have direct impact on economic, environmental and social aspects and corporate social responsibility, ultimately leading to increased productivity and profitability of the organization [20]. Several studies have shown that there are similarities and differences between lean and green practices [21,22], yet both approaches have demonstrated similar objectives towards a focus on waste reduction [19]. Even though waste types differ in terms of lean manufacturing and green production, both agree that minimizing them is crucial [21]. As such, we suggest that the adoption of lean best practices in remanufacturing processes (as a CE strategy towards lean remanufacturing) also contributes to the emergent literature on lean and green.

\section{Lean Remanufacturing}

Though lean has its roots in the automotive industry [19], the literature shows examples of the successful application across different industries and sectors, such as the service, healthcare and aerospace industries [23]. The application of lean within a remanufacturing context termed 'Lean Remanufacturing' has only recently gained the attention of researchers and practitioners [16,24]. This research suggests that the combination of remanufacturing and lean principles offers good opportunities to increase process efficiencies within the remanufacturing industry [16]. In particular, Kucner [16] highlights examples of the successful application of several lean best practices within the naval ship repair industry.

Beyond these, there are relatively few accounts in the academic literature relating to the application of lean in remanufacturing. The first reported study of lean remanufacturing was presented by Amezquita and Bras [25], which focused on an independent automotive remanufacturer of clutches. This research compared a remanufacturing process that combined both craft and mass production methods with lean manufacturing practices. A major 
benefit observed in this study was the elimination of non-value-added activities which resulted in significant cost savings, suggesting that the effectiveness of the remanufacturing process can be improved through the deployment of lean best practices. Kucner [16] also claims that lean production practices can be applied to remanufacturing operations. However, there is not simply one best way, and specific solutions must be tailored to each individual remanufacturing context. He examined four diverse remanufacturing case studies that ranged from high to low product variability. In each of the cases, the implementation of lean methods significantly improved performance, particularly in developing internal process stability, built-in quality and just-in-time (JIT) production. Fargher Jr [26] and Pawlik [27] also confirmed that the application of lean within remanufacturing can significantly reduce lead-time and work in progress (WIP), whilst simultaneously improving quality, on-time shipments and the utilization of floor space [27]. Sundin [28] used 'The Rapid Plant Assessment' (RPA) tool to investigate five remanufacturing companies (from different sectors). The results suggested that the remanufacturers performed well in the categories: 'people and teamwork', 'customer satisfaction', 'skill level and motivation', 'quality system development' and the 'ability to manage complexity and variability'. The study also identified that in most companies, categories such as 'product flow', 'visual management deployment', 'inventory and WIP level' and 'space use and material movements' presented below average, or even poor, performance, and that focus was required on these aspects in order to make the companies more lean.

Kanikuła and Koch [29] proposed nine Kanban replenishment scenarios, including: one piece flow, visual control, pull systems and value stream mapping. This research defined several 'boundary conditions' (some of which were also pointed out by Guide Jr [11]) as the key characteristics which complicate PPC activities within remanufacturing firms. Their theoretical results highlighted the need for further research to test the scenarios modelled in remanufacturing firms. In 2015, Kurilova-Palisaitiene [30] also suggested that lean efforts might bring benefits to remanufacturers. Based on a current state map and the problems identified during a workshop in a German remanufacturer, a Kanban re-ordering system was suggested, claiming a potential lead-time reduction of $69 \%$.

In respect to material flow, Hunter and Black [31] investigated the use of a cellular layout in remanufacturing. They proposed a cellular layout and claimed that it could both increase productivity and reduce inventory. Other researchers have noticed difficulties with the application of the lean tools and methods within the remanufacturing environment. Pawlik [27] identified that uncertainties about the condition of incoming cores may be the main issue influencing successful implementation. A similar conclusion was reported by Ostlin and Ekholm [32] regarding a toner cartridge remanufacturer, where both 'variable processing time' and 'uncertainties in materials recovered' limited the implementation of lean. Moreover, Amezquita and Bras [25] noticed that, because of the stochastic nature of returned products, traditional remanufacturing processes are difficult to standardize.

Seitz and Peattie [15] claimed that the differences between the challenges for conventional manufacturing and remanufacturing are significant. They observed that complications are mainly due to different product generations and the numerous variants often found within a product family. In contrast to remanufacturers, manufacturing companies usually have to deal with one generation of product at a time, allowing the manufacturer to dedicate a production line to one single product-line. Consequently, Seitz and Peattie [15] concluded that establishing the types of lean and mass production systems that (conventional) manufacturers depend upon becomes practically impossible (in remanufacturing). However, there is lack of evidence suggesting that the case company in this research made significant attempts to apply lean best practices. Ostrowski [33] discussed the application of the employee suggestion system in remanufacturing environment. He claimed that a less repeatable remanufacturing process affects the functioning of this system.

Pascual [34] presented the collaboration between the University of Valladolid and Renault-Nissan Consulting. The factory training that integrates lean manufacturing and the circular economy was discussed. Training is given not only to students but to workers 
and professionals. It was highlighted that this cooperation is currently very important. Due to limited resources, effective use must be ensured.

Given this context, the authors were motivated to investigate the application of lean best practices in contemporary remanufacturing processes to provide a detailed understanding of the relationship between lean methods and the complicating characteristics of remanufacturing. This research focuses both on the identification of lean practices that help manage the complexity in the remanufacturing processes and factors that limit the application of lean practices within remanufacturing. The conceptual framework (Figure 2) has been developed to put together the main points from the literature and guide further empirical research.

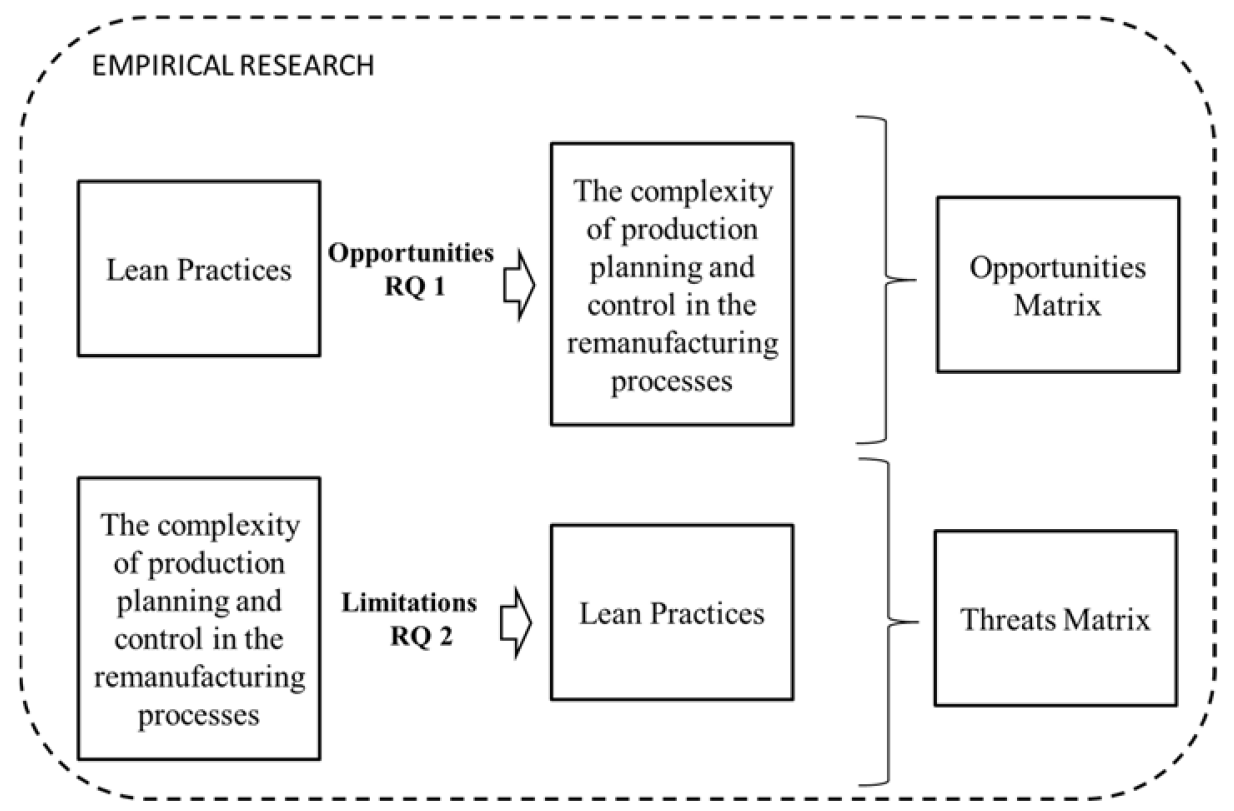

Figure 2. Conceptual framework of the investigation.

\section{Research Design and Methodology}

Seitz and Peattie [15] identified a need for more empirical research into the automotive remanufacturing process, whilst Junior and Filho [10] stated that more practical research is required into the challenges of PPC in remanufacturing. Therefore, guided by our research question, "Can the complicating characteristics of PPC activities in remanufacturing be reduced through application of lean manufacturing best practices?", the authors' adopted a case study methodology with the aim of providing insight into industrial activities and the performance of lean remanufacturers.

From a group of six potential case companies, the investigation was limited to the three enterprises that the authors deemed to have carried out the most extensive implementation of lean best practices. These companies (two British and one Polish) were selected because they were: (1) automotive remanufacturers (2) that had implemented lean production best practices. The work focused on the case study companies' shop floor activities, and the work was carried out in accordance with established guidelines for academic case-based research [35]. Data were collected using semi-structured interviews with company staff at all levels of the organization (e.g., managing director, production manager(s), leaders and employees, including production planners). To ensure that the process for collecting, presenting and analyzing the data from the interviews was robust and repeatable, the authors used a case study protocol in the form of an interview guide. Triangulation was carried out by direct observations and analysis of secondary sources (e.g., company documentation and corporate websites) to check the consistency of data [36]. Our approach strove to constantly compare theory and data, iterating towards a theory which is closely supported by the data [37]. 
Following the data collection activities at the three case study companies, case study reports were sent for review by key contacts at each company to ensure data were accurate. In addition, findings were also (anonymously) presented to managers and employees from a fourth British case company (Company D), otherwise unrelated to this study, for the sake of further feedback and validation. Company D was selected as its employees also had significant experience with the application of lean practices within a remanufacturing context. During the meeting, each complicating characteristic of PPC in remanufacturing was discussed in relation to the challenge of implementing particular lean practices.

\section{Case Studies}

This section gives a brief introduction to the case studies that were conducted.

\subsection{Case Study A}

Company A is a UK-based, OEM Remanufacturer located in Newcastle upon Tyne. The company remanufactures final drives, hydro-gas suspension units, bridging equipment and track tensioners for combat vehicles. Since the vehicles are used in extreme climates and conditions, parts are classified as 'high-wear items'. Implementation of lean remanufacturing began in 2007. The interviewee said that there was some level of success in creating a continuous improvement culture within the facility.

Due to increased competition, Company A urgently needed to reduce the price of remanufactured units. As such, the company organized a five-day Kaizen workshop. During this session, several potential improvements were identified. One of these was the requirement for quality visual standards and clear quality control instructions, as it was difficult for employees to decide if a component should be sent for remanufacture or rejected. This task was particularly difficult for new, less experienced employees.

The Kaizen event and subsequent improvement projects allowed for significant process improvement and lead time reduction. The current-state map highlighted that 23 steps and $2914 \mathrm{~min}$ (over $48 \mathrm{~h}$ ) were used to remanufacture one item. The future-state map showed that only $29 \mathrm{~h}$ were needed (40\% improvement). However, an emerging challenge was the lack of time to implement improvements, because after the event employees were too busy doing their work.

In addition to the Kaizen event, Company A continuously applies lean best practices to make small improvements to overcome problems. Moreover, the identification and elimination of waste have incrementally improved the remanufacturing process at the company. One manager said that one of the most beneficial lean tools is visual management, for example, placing safety, quality, delivery and cost $(S, Q, D, C)$ boards in process areas to present daily metrics for each category. If teams meet the goals, then the category is marked as green; if not, red. During the factory tour, it was observed that most were marked green, confirming that the company is performing well.

Before the implementation of lean at Company A, there was little control over the process and many quality issues. The first step was 5S, however, the company managed to implement only the first $3 \mathrm{Ss}$ - Sort, Set and Shine. Standardizing and Sustaining were problematic, and managers claimed that changing the company's culture was one of the most difficult tasks at Company A. Challenging fixed ideas that have been instilled for over 30 years in many cases is not easy. The manager said that, although experienced employees are critical in remanufacturing, they can make the application of lean more difficult. Moreover, the variation in the condition of cores also makes lean implementation challenging as well. The manager said: "in remanufacturing there is always some level of variation that you need to deal with". Even though standard work instructions were developed, there are many things that are not standard. The company also attempted to apply one piece flow, but this did not work. There were too many bottlenecks, and due to variations in the process and core condition, Company A has not managed to balance the line. 
The summary of lean tools and techniques that have been applied to Company A are listed in Appendix A.

\subsection{Case Study B}

Company B (based in Weston-super-Mare, UK) is one of the largest, contract automotive remanufacturers in Europe. The company was founded in the 1960s to provide commercial vehicle service and repair. This later led to remanufacturing contracts for transmissions, gears, steering, commercial engines and sub-assemblies from Bedford trucks. However, the major remanufacturing development happened in 1978 with a contract from Ford Motor Company. Currently, transmissions (manual and automatic) and engines (petrol and diesel) are the main products. Company B has 75 employees. OEMs are both the supplier of cores and the customer of remanufactured products. The company is using make-to-order production where remanufacturing starts after the customer's order is received. Furthermore, the company works closely with the manufacturing facilities and service divisions of the OEMs to support engineers with the failure mode and performance data. Their commitment to quality is demonstrated by the scope of their accreditations: ISO/TS16949:2002, ISO14001 and TS16949, FORD Q1, QS9000, ISO9002 and ISO14001. Moreover, Company B is regularly assessed by OEMs to confirm fulfillment of all requirements.

Company B started its lean journey when one of its customer's engineers visited the facility and made the first recommendation in regard to improving the process based on lean principles. Subsequently, Company B implemented 5S. The company has also standardized the way components are handled, the bench layout, workplaces and the tooling that is used. An employee can now move from one workbench to another and recognize everything that is there. Workbenches are dedicated to particular product types.

The company is identifying and eliminating nine wastes within their processes. This exceeds the seven wastes normally associated with lean because the company classifies the losses associated both with talent and energy.

Different baskets for different gearboxes have been designed to standardize transportation boxes. The company keeps all components from each gearbox in a single storage tray. This helps to control the process and ensure that respective components will be remanufactured. Moreover, it also allows simple identification of which components were removed from the core and which must be replaced with new parts.

Company B has implemented visual management. Key performance indicators (KPIs) are displayed on boards placed on the shop-floor. Employees have meetings every day to discuss the most important issues from the previous $24 \mathrm{~h}$. The company continuously improves the process and develops employee skills to improve the products. All complaints from internal or external customers are addressed using 8-step problem-solving methodology (8D) to ensure that problems do not reoccur.

The manager said that Company B has not implemented all of the lean tools because the capacity of the facility is higher than the volume of ordered units. Consequently, there is no pressure to initiate improvement activities continuously. Moreover, there was no attempt to apply SMED because each workstation is set up for a specific product, hence no changeovers are necessary.

The summary of lean tools and techniques that have been applied to Company B are listed in Appendix B.

\subsection{Case Study C}

Company $\mathrm{C}$ is an OEM remanufacturer based in Wroclaw, Poland. The facility was established in 2011 and lean methods were first introduced in 2013. The main products remanufactured within the facility are compressors and anti-lock braking systems. The company has received a certificate confirming compliance with the requirements of ISO 9001 and ISO/TS 16949. 
The main motivation to implement lean was to meet the standards set by the group. During the interview, the manager was asked about the maturity of the application of lean at Company $C$. The company's own rating system was used, where " 1 " represents lowest maturity and " 6 " highest. The manager suggested that " 3 " (medium maturity) would be an appropriate rating.

It was highlighted that the information required during the remanufacturing process changes very quickly. Therefore, apart from experienced employees, a system of communicating and sharing information was required by other staff. If an employee is unsure about the quality of the component, she leaves it in a special area with a yellow card attached to signal for an engineer to inspect that component. For remanufacturing operations dealing with large variations in product (such as Company C), it was identified that a cross-functional workforce was critical to balancing capacity with highly variable processing times. To increase flexibility, the company has implemented a skills matrix that includes all operations of the process and the list of operators who can perform them. This helps management to identify the right employees for the right tasks. Hourly production boards were introduced to provide production results compared to the plan. This creates a feedback system for estimated processes that allows problems to be identified in real time and better utilizes capacities.

The interviewee confirmed that changes to the factory layout brought a lot of benefits, as they allowed optimization of the shop floor according to the flow of the product families. Prior to this, it was often difficult to identify where the components should go from one operation to another. Moreover, the distance travelled by each product was reduced. The manager confirmed that the implementation of lean practices is easier because of the employees' engagement. There are a lot of new employees without 'old habits', such that resistance to change was not an issue during lean implementation.

It was observed that some of the lean tools have been adjusted to fit the remanufacturing environment. For example, when determining cycle-time, the variation in quality of incoming cores has to be taken into consideration. To improve flow in remanufacturing, company $\mathrm{C}$ is planning to implement Kanban. Currently, components are 'pushed' from one workstation to another in batches. This results in high inventory located between processes. It is difficult to introduce a pull system as the remanufacturing process is not stable. The company is not capable of remanufacturing consistent results over time because components often have to be removed from the process when they do not fulfill the required specification. Therefore, an extra Kanban will be located in the process to provide a suitable buffer. One of the barriers, as indicated by the manager, to the successful application of lean within the facility is a lack of time required to work on new solutions. Solving daily problems has a higher priority than implementing lean practices.

The summary of lean tools and techniques that have been applied to Company $\mathrm{C}$ are listed in Appendix C.

\subsection{Case Study D}

Company D (UK) was used to validate findings from this research, as it has extensive experience with the application of lean within a remanufacturing environment. The company has been actively remanufacturing automotive steering components and transmissions (both manual and automatic) and wind turbines since 1981. It is both an OEM and contract remanufacturer. In the case of car transmissions and steering, the company has a contract with companies such as Jaguar Land Rover. It remanufactures transmissions for passenger cars, commercial vehicles and off-road machinery. Company D offers remanufactured units for the entire range of steering technology. Each product is located in a different department:

- Car transmissions section;

- Car steering section;

- Wind turbine section. 
First, the core is cleaned and inspected to ensure that it is complete to the specification. Then it is stripped down, cleaned again and various parts are again inspected. All seals, synthetic and plastic parts are replaced. Some components must go through a machining operation to fulfill quality requirements. Then, products are rebuilt and tested.

Lean was introduced in 2004 in one of the sections by drawing spaghetti diagrams. The main motivation to implement lean was to greater satisfy the customer by reducing throughput times. It was observed that operators were walking several kilometers to build one gearbox, and as such, the layout was changed to eliminate excessive movement and transportation.

Managers suggested that it was people that at first seemed to be the main factor limiting the application of lean within the facility. Employees were stressed about losing their jobs if things would be completed faster. As such, communication played an important part in successfully implementing lean. For example, an 'introduction to lean' workshop was organized. Management took part in training together with employees. The workshop covered many lean concepts including waste, Kaizen, pull system, etc. Besides the workshop, management constantly assured employees that lean is not about reducing headcount. They highlighted that if the product was cheaper, the facility will sell more, and the company will have more work and will create more jobs.

\section{Alleviating the Complicating Characteristics of PPC Activities in Remanufacturing through the Implementation of Lean Best Practices}

Implicit in the first research question is the hypothesis that remanufacturers are able to mitigate the complicating characteristics of PPC activities in remanufacturing by selecting and implementing specific lean best practices to address specific problems. Using the results of the case studies, Table 1 details the complicating characteristics that might be addressed by applying specific lean practices. We refer to the case studies as evidence of the effectiveness of particular lean practices being applied in remanufacturing processes.

Table 1. Opportunities matrix.

\begin{tabular}{|c|c|c|c|c|c|c|c|c|c|c|}
\hline & & \multicolumn{9}{|c|}{ Lean Manufacturing Best Practices } \\
\hline & & $\begin{array}{l}\text { Standardized } \\
\text { Work In- } \\
\text { structions }\end{array}$ & Standardization & Kanban & $\begin{array}{c}\text { Cross- } \\
\text { Functional } \\
\text { Workforce }\end{array}$ & $\begin{array}{l}\text { Production } \\
\text { Analysis } \\
\text { Board }\end{array}$ & $5 S$ & $\begin{array}{c}\text { Visual } \\
\text { Management }\end{array}$ & $\begin{array}{c}\text { Cellular } \\
\text { Manufactur- } \\
\text { ing }\end{array}$ & TPM \\
\hline \multirow{5}{*}{$\begin{array}{l}\text { Complicating } \\
\text { Characteris- } \\
\text { tics }\end{array}$} & $\begin{array}{l}\text { Disassembly } \\
\text { of returned } \\
\text { products }\end{array}$ & $x$ & & & & & & & & \\
\hline & $\begin{array}{c}\text { Material } \\
\text { matching } \\
\text { restrictions }\end{array}$ & & $x$ & & & & & & & \\
\hline & $\begin{array}{l}\text { Uncertainty } \\
\text { in } \\
\text { materials } \\
\text { recovered }\end{array}$ & $x$ & $x$ & $x$ & & & & & & \\
\hline & $\begin{array}{c}\text { Highly } \\
\text { variable } \\
\text { processing } \\
\text { time }\end{array}$ & $x$ & $x$ & & $x$ & $x$ & & $x$ & $x$ & \\
\hline & $\begin{array}{c}\text { Stochastic } \\
\text { routings }\end{array}$ & & & & & & $X$ & & & $x$ \\
\hline
\end{tabular}

The following subsections detail each of the complicating characteristics that can be mitigated by a lean practice.

\subsection{Disassembly of Returned Products}

The challenge of disassembling returned cores can be alleviated through:

- $\quad$ Standardized Work Instructions

All interviewed managers confirmed that disassembly of the used product is difficult, as it requires knowledge on how to deal with components of unknown quality. Typically, this knowledge is developed over time. Working with worn or eroded components is 
always problematic, but it becomes even more difficult when the products have not been designed with disassembly in mind, as components can be damaged or destroyed during disassembly. This leads to less predictable material recovery rates and generates more waste. To reduce variability, best practices for disassembly should be documented and shared with employees to make such operations more effective. Employees are encouraged to share best practices with each other. In other words, experienced employees should not keep tips on how to perform particular tasks to themselves but make these explicit so other employees can learn. Standardized work processes should be displayed at the workstation and continuously reviewed and improved.

\subsection{The Complication of Material Matching Restrictions}

The complication of material matching restriction can be eased through:

- $\quad$ Standardization (e.g., standardization of transportation boxes)

In some remanufacturing operations, cores have to be reassembled using exactly the same components (e.g., for safety reasons or customer requirements). Remanufacturers must ensure that this requirement is fulfilled. Having several cores at the same time, within a process, makes this difficult. Keeping all components in one basket can prevent loss or separation (without documentation) while moving between operations. Moreover, when parts from several cores are stored together, it is more difficult to notice if anything is missing. This situation is most frequently observed at the end of the process during the reassembly, when it is likely to be too late and, as a result, the product cannot be reassembled.

\subsection{Uncertainty in Materials Recovered from Returned Items}

Uncertainty in materials recovered from returned items can be alleviated by applying:

- Kanban

In most remanufacturing processes, some components must be replaced with new ones. However, it is difficult to predict how many new components will be required. In remanufacturing, company planning specialists have to keep track of new components consumed in the remanufacturing process and predict how many components should be ordered to fulfill the future remanufacturing plan. To support component supplies transportation, Kanban can be implemented. Transportation Kanban gives permission to material handlers to move products and components. This system ensures that stock is available without excessive inventory. With Kanban, the order is made based on actual need. However, due to the high variability of products, not all spare components can be kept in stock. When more unusual items are required they must be ordered on-demand, increasing lead-time.

\section{- $\quad$ Standardized Work Instructions}

Standardized work instructions relieve the negative effect of uncertainty in materials recovered from returned items. Prior to implementing standardized work, deciding whether the component should be used or rejected was mainly based on employees' judgement. Thus, this task could be performed only by experienced employees, because the consequence of the wrong decision has an influence on the whole business. Wrongly rejected components cost money. Keeping components that had to be rejected in the following operations also causes additional cost. Standardized work instructions provide clear guidelines, according to which the components are assessed.

- Standardization (standardization of transportation boxes)

Remanufacturers must purchase replacement parts (for those that cannot be reused from cores) in advance, so as to prevent waiting. This results in delays for the customer. Interviewees suggested that having all components placed in transportation boxes allows rapid identification when any component is missing or has been discarded in any step of the process, and thus the replacement can be ordered on time. Previously, information 
about missing parts often was not available until reassembly. As a result, the company had to keep a higher stock of spare components to react to such situations.

\subsection{Highly Variable Processing Times}

Highly variable processing times due to uncertainties about the quality of incoming cores can be relieved through the application of:

\section{- Cross-Functional Workforce}

Highly variable processing times are a challenge for most remanufacturing companies, a consequence of which is that operations might require more time and human effort than anticipated. When an operation requires more time than initially planned for, managers can assign additional operators to the job. However, this is only possible if there is a qualified operator available. Consequently, it is critical to have multi-skilled employees to help reduce uncertainties associated with the quality of incoming cores and highly variable processing times by increasing flexibility and simplifying the planning process. When necessary, a skills matrix enables managers to visually recognize which employees have the necessary competencies for particular operations.

- Standardization (standardization of kits)

It is difficult to plan a remanufacturing process because of the uncertainties of incoming cores. Introducing the standardization of kits appears to offer advantages for remanufacturers. Defining standards in terms of the work required to remanufacture (e.g., light, medium or heavy) helps to reduce levels of uncertainty involved with the different conditions of cores. Before the process starts, an engineer inspects components and classifies them as a light, medium or heavy kit. Each kit type has a pre-determined time and effort for remanufacture. This is important information for planning specialists so they can more precisely plan the remanufacturing process. The case studies demonstrated the advantages of using such an approach.

- Visual Management (production analysis board)

Visual control boards display performance status and communicate problems. Any deviation that occurs within the process is highlighted and discussed each day. It was confirmed in the case studies that the identification of abnormalities is critical for improving the process. When the workstation does not accomplish the plan, the leader needs to identify the cause. New problems involving the quality of incoming cores emerge constantly in remanufacturing, therefore, it is very important to identify them rapidly to improve the process. Every few hours, the production manager, together with the engineer, analyzes the identified problems. Even if the problem cannot be 'solved' within the facility, the knowledge is still important information for the planning specialist, who can note that the time required to remanufacture this type of defect is longer.

\section{- $\quad$ Standardized Work Instructions}

Variation in employee skills and experiences can also cause processing time to vary. To reduce such variation, standardized work instructions have been implemented in all case companies. Current best practices for each operation are identified, documented and shared with all employees to make operations more efficient. Managers confirmed that this is a powerful tool that allows visualizing the content of work processes.

\section{- Cellular Manufacturing}

In conventional manufacturing, depending on production volumes, a number of employees can work within a cell to fulfill customer demand. Similarly, in remanufacturing, a number of people can work within the cell depending on the quality of incoming products and the time required to complete the work.

\subsection{Stochastic Routing of the Material}

Stochastic routing of the material can be accommodated through the application of: 


\section{- $\quad 5 S$}

$5 \mathrm{~S}$ can be implemented as a form of visual management. If cleanliness and order is not being maintained at a workstation (e.g., the material is not stored in its correct locations or tools are not put back in the appointed place), $5 \mathrm{~S}$ allows everybody to see this at a glance. It also helps to maintain discipline at the workstation, so when an extra operation needs to be performed, time is not wasted by looking for necessary tools. This is particularly important in remanufacturing, where so many uncertainties exist.

\section{- Total Productive Maintenance}

The deployment of TPM can help to ensure that remanufacturing equipment is available whenever a particular operation is required. It is a way of increasing the reliability of production machinery.

\section{Factors That Limit the Application of Lean Manufacturing Practices within Remanufacturing Firms}

The previous section concentrated on the major complicating characteristics of PPC found in remanufacturing processes, and how these challenges can be eased by implementing lean practices. In some cases, however, these characteristics may indeed hamper the application of lean best practices within a remanufacturing environment. Table 2 summarizes which of the complicating characteristics limit the application of lean tools within the remanufacturing environment, before the following subsections link the issues to specific examples in the case studies.

Table 2. Threats matrix.

\begin{tabular}{|c|c|c|c|c|c|c|}
\hline & & \multicolumn{5}{|c|}{ Lean Manufacturing Best Practices } \\
\hline & & $\begin{array}{c}\text { First-in-First- } \\
\text { Out } \\
\text { (FIFO) }\end{array}$ & $\begin{array}{c}\text { Standardized } \\
\text { Work } \\
\text { Instructions }\end{array}$ & $\begin{array}{l}\text { Transport } \\
\text { Kanban }\end{array}$ & $\begin{array}{l}\text { Production } \\
\text { Kanban }\end{array}$ & $\begin{array}{c}\text { Cellular } \\
\text { Manufacturing }\end{array}$ \\
\hline \multirow{5}{*}{$\begin{array}{l}\text { Complicating } \\
\text { Characteristics }\end{array}$} & $\begin{array}{l}\text { Disassembly of } \\
\text { returned } \\
\text { products }\end{array}$ & & & & & \\
\hline & $\begin{array}{l}\text { Material } \\
\text { matching } \\
\text { restrictions }\end{array}$ & $x$ & & & & \\
\hline & $\begin{array}{l}\text { Uncertainty in } \\
\text { materials } \\
\text { recovered }\end{array}$ & & $X$ & $\mathrm{X}$ & $\mathrm{X}$ & \\
\hline & $\begin{array}{l}\text { Highly variable } \\
\text { processing time }\end{array}$ & & $x$ & & & \\
\hline & $\begin{array}{c}\text { Stochastic } \\
\text { routings }\end{array}$ & $x$ & $x$ & & & $x$ \\
\hline
\end{tabular}

\subsection{Stochastic Routings for Material for Remanufacturing Operations}

Stochastic routings of material for remanufacturing operations limit the application of: - $\quad$ FIFO

The case studies suggested that it is difficult to ensure that the first part which enters a process or a storage location is also the first part to exit in remanufacturing environments, because similar parts might require different processes (e.g., some operations might be omitted or components will have to go through additional treatments to fulfill customer requirements). Furthermore, in some cases, components have to go through the same operation more than once. As a result, parts often leave the system in a different sequence from which they entered (Figure 3). 


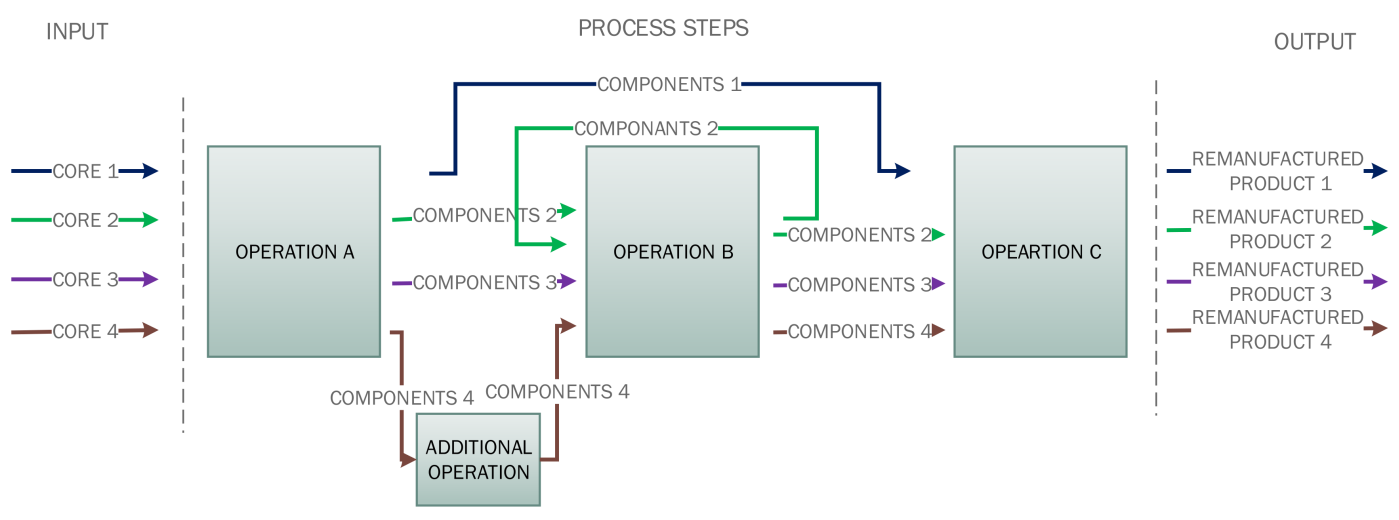

Figure 3. First-In First-Out in remanufacturing context.

\section{- Standardized Work Instructions}

It has already been confirmed that standardized work instructions have been implemented successfully within a remanufacturing process. However, establishing precise procedures for each operator's work is difficult. It was previously mentioned that remanufacturing contains additional characteristics that increase inconsistency within the process. Depending on the quality of returns, like parts may need different processes for recovery. Moreover, additional activities not covered by existing standards are often necessary to bring a product to the required condition. In that case, employees cannot perform an activity repeatedly, and their experience is invaluable.

\section{- Cellular Production}

It is difficult to fully implement cellular production when not every operation is required. In some companies, regardless of the quality of the core, the components must pass through all operations. However, in other companies, the quality is first assessed to determine which operations are required. This was the case in Company B, where, depending on the quality, some operations could be omitted (Figure 4). Moreover, the interviewee admitted that it would be difficult to dedicate machines and processes to just one remanufacturing cell.

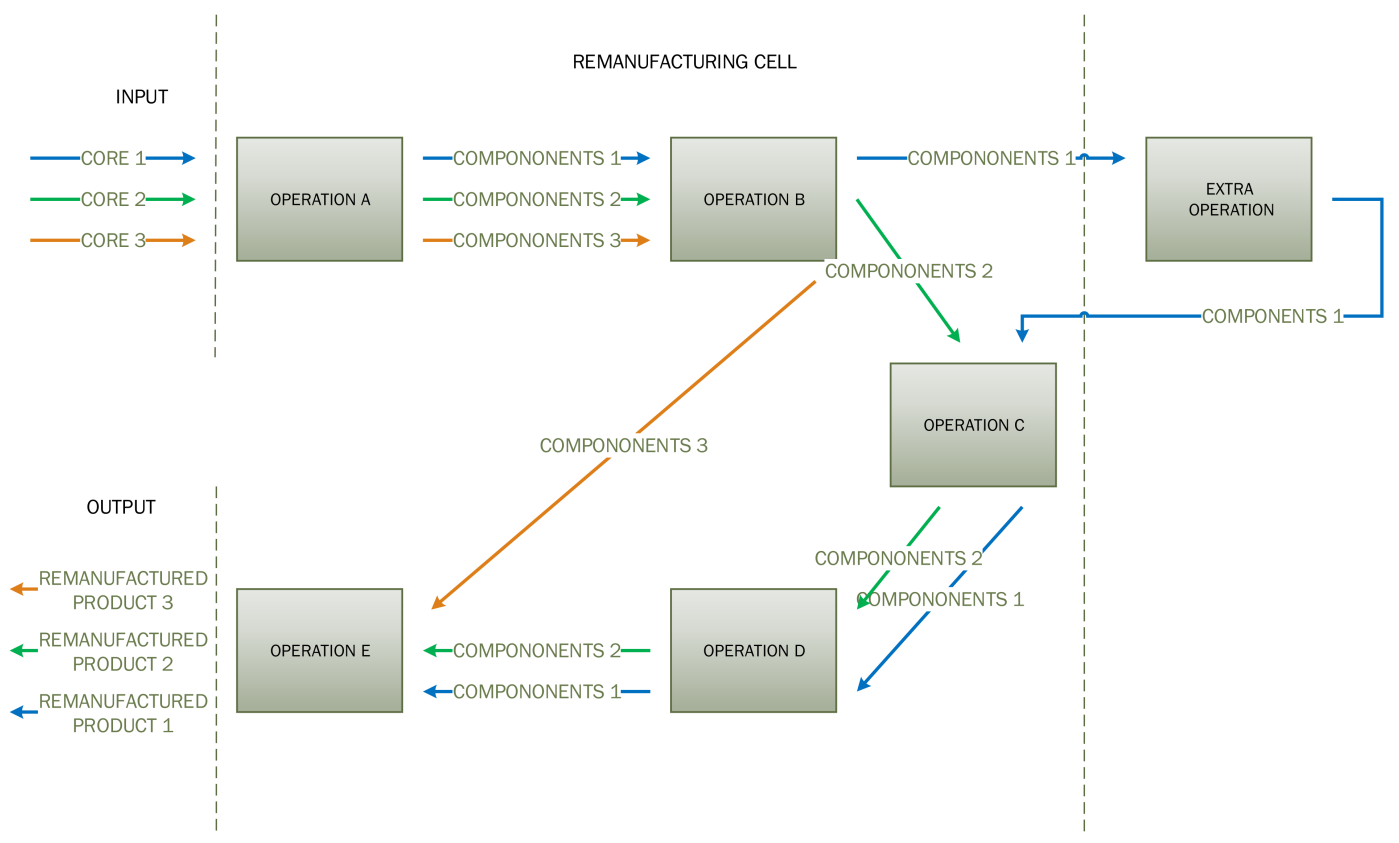

Figure 4. Material flow in remanufacturing cell. 


\subsection{Uncertainty in Materials Recovered from Returned Items}

The case studies highlighted that uncertainty in materials recovered from returned items limits the application of the:

\section{- Transportation Kanban}

It was confirmed that implementation of transportation Kanban is only possible for certain components. As a consequence of high variability of products and uncertainty in materials recovered from returned items, it would not be feasible to keep all parts that may be required to remanufacture each unit. Moreover, there is also the risk of obsolescence.

\section{- $\quad$ Standardized Work Instructions}

Establishing precise procedures for each operator's work in a remanufacturing process is difficult. Not all possibilities can be covered by standards. Thus, uncertainty in materials recovered from the returned items is difficult to predict, as well as which parts will be required to remanufacture a particular unit. Very often, because of the age of the cores, a significant amount of time is required to obtain spare parts. When the customer is not willing to wait, no standard operations are required to provide missing components.

\section{- Production Kanban}

As a result of the uncertainty in material recovered from returned items, components can be rejected from the process, and the customer will not receive the required number of products. Adding extra parts to each Kanban might solve that issue, however, more research will be required to calculate the quantity of these components (Figure 5).

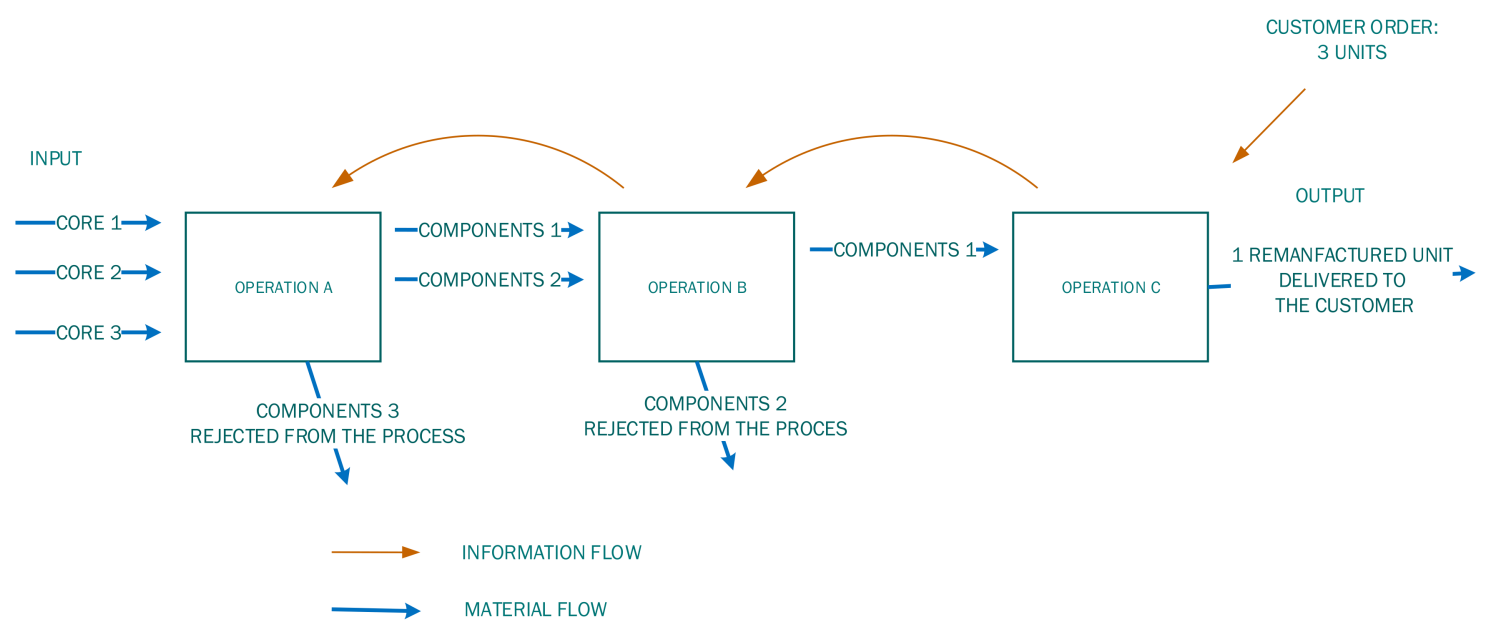

Figure 5. Production Kanban in remanufacturing environment.

\subsection{The Complications of Material Matching Restrictions}

The complications of material matching restrictions together with the uncertainty of material matching restrictions make the following difficult to apply:

- $\quad$ First In First Out (FIFO)

Often, when components have their own unique part numbers, it is important to reassemble a core using exactly the same components. When the quality is not good enough, the component must be taken out of the process and a decision must be made whether to reject it from the process. When the component cannot be remanufactured, a new one has to be obtained. As a result, the whole product has to be removed from the process and reintroduced when the new component arrives.

\subsection{Highly Variable Processing Time}

This study has identified that highly variable processing time limits the application of the: 


\section{- $\quad$ Standardized Work Instructions}

Standard time required to perform each activity should be established and included in the work instructions [38]. However, similar components taken from different products might require different degrees of treatment for equal operations.

\section{Conclusions and Further Work}

The research developed in this study presents a more holistic understanding of the application of lean best practices within remanufacturing to help manage the inherent complexity of the remanufacturing processes and, consequently, improve the overall productivity of the process. The following outputs of this study contribute to academic knowledge about lean remanufacturing:

\section{Opportunities Matrix}

Provides new knowledge about how the applications of lean practices reduce the impact of complexity on production planning and control in remanufacturing processes. Importantly, it cites specific examples from the case study companies of the impact of lean practices on the complexities of the remanufacturing process.

\section{Threats Matrix}

Provides new knowledge about the application limits of particular lean tools within the remanufacturing process. It identifies which lean practices are negatively affected by which complexities of the remanufacturing process.

Similar conclusions have been reported by other researchers who conducted similar investigations in parallel with this one. For example, Kurilova-Palisaitine [39] developed suggestions to tackle remanufacturing challenges with the aim of shorter lead time. Potential improvements have been identified as a result of focus group interviews [39]. One highlight is that the discussed lean tools should be tested and verified at remanufacturing companies. However, this investigation observed and verified practices used in case companies who are already applying lean methods in remanufacturing processes. Despite the differences in methodology, it is interesting to compare the findings of the two investigations. For example, [39] states that "by communicating in the standard way, the challenges related to the core and spare part information flow can be diminished". The work also suggests that the introduction of instructions might reduce uncertainties related to the task being performed. To achieve that aim, both images and text can be used. Similar conclusions have been achieved from this research, where it was confirmed that standardized work instruction has been implemented in all companies used in this research. One way to accomplish continuous flow is to apply a cellular layout. Again, Kurilova-Palisaitiene [39] noticed that "a cellular factory layout for continuous flow is beneficial in terms of solving the high inventory levels challenge and, together with the Kanban ordering system, has the greatest effect on lead-time reduction". However, in this research, it was identified that cellular manufacturing can be very challenging to implement when not every remanufacturing operation is required to remanufacture units, or some additional ones are needed. The reduction in lead times through the implementation of a cell layout can be achieved in remanufacturing companies where each component has to go through each operation regardless of the quality of the unit. Moreover, Kurilova-Palisaitiene [39] has noticed that" a cellular layout allows quick adjustments in the number of employees at the work stations". It was also confirmed by our case companies that a cellular layout is particularly useful when a longer time is required to remanufacture cores (as a result of its condition). Then, more employees are dedicated to a particular cell in regard to completing the process in a given time.

Kurilova-Palisaitiene [39] also noted that "A great improvement resulting from the transformation of the ordering system to the Kanban is control of the inventory level at the remanufacturing site". In contrast, this research has observed that a transportation Kanban had been implemented within Company B and Company C. It was identified that the application of Kanban helps to track the volume of components that are required to fulfil 
customer requirements. This gives assurance that the required components are available and excessive stock levels can be avoided. However, because of the high variability of products, not all spare components can be covered by the Kanban system. Finally, Kurilova-Palisaitiene [39] highlighted that employee cross-training and learning (through problem solving) are important in remanufacturing, since remanufacturers are currently very dependent on manual work. All of the case companies studied in our research have implemented a cross-functional workforce. It was highlighted that the application of this lean best practice is critical in regard to reducing any uncertainty involved with highly variable processing times.

When considering these matrices, one should recall that the lean philosophy is not simply a process of implementing a fixed list of best practices, but a process of discovering what firms (and individuals) need to learn in order to improve. As such, the best practices associated with lean production systems become frames to accelerate learning [40]. Consequently, further research should focus on these limitations, particularly how these lean manufacturing best practices could evolve to be better suited to addressing the challenges of remanufacturing firms. The validation study also confirms the usefulness and relevance of matrices for practical application. Thus, the matrices not only provide an original contribution to knowledge but also a practical contribution to the field, because practitioners can use this study to choose a suitable lean practice to overcome the negative effect of remanufacturing complexities, thus making PPC activities in remanufacturing simpler to execute. In other words, the opportunities matrix can be used by remanufacturing managers to guide their selection of lean practices that could be appropriate to their particular product. For example, when a complication of material matching restrictions makes production planning and control difficult to execute, managers can make a decision that the standardization of transportation boxes should be implemented within the facility.

Finally, as this investigation focused only on the application of specific lean best practices with a view to alleviating the inherent complexity of remanufacturing processes, we suggest that further work should examine the supplementary application of green practices to further enhance the impact of lean and green on sustainable remanufacturing operations.

Author Contributions: Conceptualization, E.P.; methodology, E.P. and W.I.; validation, E.P.; formal analysis, E.P.; investigation: E.P. and D.P.; data curation, E.P.; writing—original draft preparation, E.P.; writing-review and editing, W.I., J.C. and D.P.; visualization, E.P.; supervision, W.I. and J.C. All authors have read and agreed to the published version of the manuscript.

Funding: This research received no external funding.

Institutional Review Board Statement: Not applicable.

Informed Consent Statement: Not applicable.

Data Availability Statement: Not applicable.

Acknowledgments: The authors give thanks to the case study companies who agreed to host us at their facilities and to the interviewed employees who shared their knowledge and experience to support this research.

Conflicts of Interest: The authors declare no conflict of interest. 


\section{Appendix A. Lean Practices Implemented in Company A}

Table A1. Selected lean tools and principles applied to Company A.

\begin{tabular}{|c|c|}
\hline Practices & Description \\
\hline $5 S$ & $\begin{array}{l}\text { Company A has applied } 5 S \text { in certain areas. There are clear examples of Sorting, Setting in order and Systematic } \\
\text { cleaning in the plant. } \\
\text { However, Standardizing and Self-discipline have proved difficult to maintain, even though the company does use } \\
\text { daily, weekly and monthly checklists. }\end{array}$ \\
\hline $\begin{array}{l}\text { Standardized } \\
\text { Work Instructions }\end{array}$ & $\begin{array}{l}\text { Company A has standards for all disassembly processes. The company also reassembles and tests using them, such } \\
\text { that everything is controlled from that perspective. It determines the time required to accomplish each operation, as } \\
\text { well. Standards have proven to be a very important tool for the remanufacturing process. } \\
\text { Even though the introduction of such a tool has been successful, it has been difficult to cover all remanufacturing } \\
\text { aspects due to variations inherent to this type of production. }\end{array}$ \\
\hline Standardization of kits & $\begin{array}{l}\text { The company introduced the standardization of remanufacturing kits in terms of the work required to } \\
\text { remanufacture as light, medium and heavy. }\end{array}$ \\
\hline $\begin{array}{l}\text { Cross-functional } \\
\text { workforce }\end{array}$ & $\begin{array}{l}\text { Employees at Company A are fully skilled to do any job on the shop floor. This means that they can be easily } \\
\text { transferred to another workplace when required to do so. }\end{array}$ \\
\hline Visual Management & $\begin{array}{l}\text { One of the most successfully implemented toolsets at Company A has been visual } \\
\text { management. This tool assists with communication and area configuration. }\end{array}$ \\
\hline $\begin{array}{l}\text { Kaizen Employee } \\
\text { Suggestion Program }\end{array}$ & $\begin{array}{l}\text { The identification and elimination of waste have been a major part of the improvement } \\
\text { approach at Company A. All work areas are driven by continuous improvement principles. Teams of employees } \\
\text { suggest improvements and ensure that they are implemented in due course. Documents to record and follow up } \\
\text { with employee's concerns/improvements were designed and successfully implemented. A feedback procedure is } \\
\text { also established within this program, and the continuous improvement workshop is the obvious platform for } \\
\text { such a process. }\end{array}$ \\
\hline Value Stream Mapping & $\begin{array}{l}\text { Value stream mapping (VSM) has been a major focus of Company A, and was one of the most valuable tools for the } \\
\text { company. By using VSM, Company A was able to visualize the flows (both material and information) of the } \\
\text { remanufacturing process, which helped the company to identify and eliminate waste. }\end{array}$ \\
\hline A3 & The company is using A3 reports to communicate. \\
\hline Kaizen Event & The 5-day workshop was organized in regard to identifying an improvement in a process. \\
\hline Cellular Manufacturing & $\begin{array}{l}\text { Remanufacturing of the four major product types (hydro gas, final drives, track tensioners, bridging equipment) } \\
\text { takes place in focused areas of the factory. This ensures that the correct tools and necessary process equipment are } \\
\text { located at the point of use, which simplifies the remanufacturing process. } 5 \mathrm{~S} \text { and Visual Management help to } \\
\text { structure the cellular manufacturing efforts at Company A. }\end{array}$ \\
\hline
\end{tabular}

\section{Appendix B. Lean Practices Implemented in Company B}

Table A2. Selected lean tools and principles applied to Company B.

\begin{tabular}{|c|c|}
\hline Practices & Description \\
\hline $5 S$ & $\begin{array}{l}\text { Company B has applied 5S. Each tool has its place on a workstation and each bench is dedicated to a particular } \\
\text { product type. This means that operators can move from one area to another and recognize everything that is there. } \\
\text { When any of the tools required to remanufacture a unit are missing, it is easy to notice. }\end{array}$ \\
\hline $\begin{array}{l}\text { Cross-Functional } \\
\text { Workforce }\end{array}$ & $\begin{array}{l}\text { Company B uses ' } 3 \text { one } 3 \text { ' training, in which every person can do a minimum of three jobs and every job can be } \\
\text { carried out by at least } 3 \text { people. This means that employees receive training to develop skills so that they have the } \\
\text { capacity to work across different areas of the factory. }\end{array}$ \\
\hline $\begin{array}{l}\text { Kaizen Employee } \\
\text { Suggestion Program }\end{array}$ & $\begin{array}{l}\text { Employees can make suggestions for improving the process. These improvements are } \\
\text { systematically carried out and followed up by the shop floor teams using PDCA. } \\
\text { Employees are rewarded for implemented improvements. }\end{array}$ \\
\hline Transportation Kanban & $\begin{array}{l}\text { Company B uses transportation Kanban only for a selected few (replacement) components. Thanks to that, the } \\
\text { inventory level can be kept low for these components and available when required. }\end{array}$ \\
\hline Visual Management & $\begin{array}{l}\text { Key performance indicators are displayed on communication boards within the shop floor area. Moreover, the } \\
\text { expected results vs. actual performance of cleaning operations are } \\
\text { displayed all the time. }\end{array}$ \\
\hline $\begin{array}{l}\text { Standardized Work } \\
\text { Instructions }\end{array}$ & $\begin{array}{l}\text { The sequence of movements is standardized and work instructions are displayed at the workstation to support the } \\
\text { remanufacturing operations. }\end{array}$ \\
\hline Standardization of Transportation Boxes & $\begin{array}{l}\text { Transportation boxes are designed with custom-shaped holes (or compartments) for each component for the } \\
\text { different products. Boxes are designed in such a way to ensure that all } \\
\text { required components for a specific product can be kept together, allowing deviations to be instantly recognised. }\end{array}$ \\
\hline Total Productive Maintenance (TPM) & Company B uses TPM to involve the operators in the maintenance of their equipment. \\
\hline 8D Solving Problem & $\begin{array}{l}\text { All complaints from an internal or external customer must be addressed with the } 8 \mathrm{D} \text { process to ensure that a similar } \\
\text { problem will not reoccur. An 8-step problem-solving methodology is used to find rapid and lasting solutions by a } \\
\text { team of employees. }\end{array}$ \\
\hline
\end{tabular}




\section{Appendix C. Lean Practices Implemented in Company C}

Table A3. Selected lean tools and principles applied to Company C.

\begin{tabular}{|c|c|}
\hline Practices & Description \\
\hline $\begin{array}{l}\text { Kaizen Employee } \\
\text { Suggestion Program }\end{array}$ & $\begin{array}{l}\text { Applied within the whole remanufacturing process-Suggestion system within the } \\
\text { company is used to generate ideas for improvement. }\end{array}$ \\
\hline $5 S$ & $\begin{array}{l}\text { Applied within the whole remanufacturing process-The place for everything is defined. To } \\
\text { sustain the } 5 \text { S program within a facility, audits are performed (each week, one of the } \\
\text { areas is inspected). Currently, the aim is } 90 \% \text {. After the audit, the 'owner' of the area is } \\
\text { obligated to fix everything highlighted in the audit. }\end{array}$ \\
\hline $\begin{array}{l}\text { Total Productive } \\
\text { Maintenance (TPM) }\end{array}$ & $\begin{array}{l}\text { Applied within the whole remanufacturing process-Operators, before they will start to } \\
\text { work, are obligated to investigate (according to the checklist) whether the machine is } \\
\text { working properly (there is no leakage, etc.). Moreover, preventive maintenance is scheduled } \\
\text { and performed by the Maintenance Department. }\end{array}$ \\
\hline $\begin{array}{l}\text { Cross-Functional } \\
\text { Workforce }\end{array}$ & $\begin{array}{l}\text { Applied within the whole remanufacturing process-Employees are trained to work on } \\
\text { more than one workstation. Every two hours, a rotation among different workstation occurs. } \\
\text { The skills matrix is regularly reviewed and updated. }\end{array}$ \\
\hline Production Kanban & $\begin{array}{l}\text { Applied within the reassembly area-To signal permission to take material from warehouse } \\
\text { to reassembly unit. }\end{array}$ \\
\hline Cycle Time & $\begin{array}{l}\text { Applied within the reassembly area-Cycle time is defined within the reassembly area. This } \\
\text { is difficult in regard to disassembly and remanufacturing area, as the work content, } \\
\text { operator skills and machine cycle time vary with the quality of incoming cores. }\end{array}$ \\
\hline $\begin{array}{l}\text { Standard of Dealing } \\
\text { with Faulty Parts }\end{array}$ & $\begin{array}{l}\text { Applied within the whole remanufacturing process-If the employee is not sure about the } \\
\text { quality of the component, he or she leaves that component in a special area with a yellow } \\
\text { card attached. It is a signal for the engineers to inspect that component. }\end{array}$ \\
\hline $\begin{array}{l}\text { Standardized } \\
\text { Work Instructions }\end{array}$ & $\begin{array}{l}\text { Applied within the whole remanufacturing process-Work instructions are included in each } \\
\text { workstation and define the steps required to complete work on each workstation. } \\
\text { These include acceptability criteria for components to support the decision-making process. }\end{array}$ \\
\hline $\begin{array}{l}\text { Production } \\
\text { Analysis Board }\end{array}$ & $\begin{array}{l}\text { Applied within the whole remanufacturing process-These are near machines and } \\
\text { workplaces and they show how the output looks in regard to the plan from hour to hour. If } \\
\text { the plan is not achieved, the reason for that needs to be written down. The hourly board is a } \\
\text { visualization of the problems at the shop floor level. }\end{array}$ \\
\hline Problem Solving & $\begin{array}{l}\text { Applied within the whole remanufacturing process-If a problem is identified, a root cause } \\
\text { analysis is conducted to ensure that it will not happen again. The solution is defined and } \\
\text { applied. QRQC, 5W1H and Ishikawa Diagram are used. }\end{array}$ \\
\hline FIFO & $\begin{array}{l}\text { Applied within the reassembly area-Employees take the oldest core for the further } \\
\text { process. Because the inventory between some workstations is high, a spreadsheet is used to } \\
\text { show which item should take to ensure FIFO. Each unit, no matter the quality, has to } \\
\text { undergo all remanufacturing operations. }\end{array}$ \\
\hline Visual Management & $\begin{array}{l}\text { Applied within the whole remanufacturing process-Every day, leaders, engineers and the } \\
\text { shift managers have a meeting in front of the area board to discuss performance, quality, } \\
\text { safety and the main problems that occurred in the last } 24 \mathrm{~h} \text {. Similar routines also function at } \\
\text { a higher level of management. KPIs are displayed on a board. }\end{array}$ \\
\hline Cellular Manufacturing & $\begin{array}{l}\text { Applied with the whole remanufacturing process-Successfully implemented. Products } \\
\text { flow through the cell in small lots. }\end{array}$ \\
\hline
\end{tabular}

\section{References}

1. Lieder, M.; Rashid, A. Towards circular economy implementation: A comprehensive review in context of manufacturing industry. J. Clean. Prod. 2016, 115, 36-51. [CrossRef]

2. Ijomah, W. A Model-Based Definition of the Generic Remanufacturing Business Process. Ph.D. Thesis, University of Plymouth, Plymouth, UK, 2002.

3. Gunasekara, H.; Gamage, J.; Punchihewa, H. Remanufacture for sustainability: Barriers and solutions to promote automotive remanufacturing. Procedia Manuf. 2020, 43, 606-613. [CrossRef] 
4. $\quad$ Lund, R.T. Remanufacturing: The Experience of the United States and Implications for Developing Countries; The World Bank: Washington, DC, USA, 1985.

5. van Loon, P.; Van Wassenhove, L.N. Assessing the economic and environmental impact of remanufacturing: A decision support tool for OEM suppliers. Int. J. Prod. Res. 2018, 56, 1662-1674. [CrossRef]

6. Nasr, N.; Hilton, B.; German, R. A framework for sustainable production and a strategic approach to a key enabler: Remanufacturing. In Advances in Sustainable Manufacturing; Springer: Berlin/Heidelberg, Germany, 2011.

7. Ijomah, W.L.; Childe, S.; McMahon, C. Remanufacturing: A key strategy for sustainable development. In Proceedings of the 3rd International Conference on Design and Manufacturing for Sustainable Development; Cambridge University Press: Cambridge, UK, 2004. Available online: https://pureportal.strath.ac.uk/en/publications/remanufacturing-a-key-strategy-for-sustainabledevelopment (accessed on 20 December 2021)ISBN 1-86058-470-5.

8. Nasr, N.; Thurston, M. Remanufacturing: A key enabler to sustainable product systems. In Proceedings of the 13th CIRP International Conference on Life Cycle Engineering, Lueven, Belgium, 31 May-2 June 2006.

9. Xia, X.; Zhang, C. The impact of authorized remanufacturing on sustainable remanufacturing. Processes 2019, 7, 663. [CrossRef]

10. Junior, M.L.; Filho, M.G. Production planning and control for remanufacturing: Literature review and analysis. Prod. Plan. Control. 2011, 23, 419-435. [CrossRef]

11. Guide, V.D.R., Jr. Production planning and control for remanufacturing: Industry practice and research needs. J. Oper. Manag. 2000, 18, 467-483. [CrossRef]

12. Steinhilper, R. Remanufacturing - The Ultimate Form of Recycling; Fraunhofer IRB Verlag: Stuttgart, Germany, 1998.

13. Statham, S. Remanufacturing towards a More Sustainable Future (Online). 2006. Available online: https://www.lboro.ac.uk/ microsites/mechman/research/ipm-ktn/pdf/Technology_review/remanufacturing-towards-a-more-sustainable-future.pdf (accessed on 20 December 2021)

14. Lundmark, P.; Sundin, E.; Björkman, M. Industrial challenges within the remanufacturing system. In Proceedings of the 3rd Swedish Production Symposium 2009, Göteborg, Sweden, 2-3 December 2009.

15. Seitz, M.A.; Peattie, K. Meeting the Closed-Loop Challenge: The Case of Remanufacturing. Calif. Manag. Rev. 2004, 46, 74-89. [CrossRef]

16. Kucner, R.J. A Socio-Technical Study of Lean Manufacturing Deployment in the Remanufacturing Context; University of Michigan: Ann Arbor, MI, USA, 2008; ISBN 9780549986393.

17. Sundin, E. Product and Process Design for Successful Remanufacturing. Ph.D. Thesis, Linköping University, Linköping, Sweden, 2004.

18. Matsumoto, M.; Ijomah, W. Remanufacturing. In Handbook of Sustainable Engineering; Lee, K.-M., Kauffman, J., Eds.; Springer: Berlin, Germany, 2013; ISBN 9781402089398

19. Womack, J.P.; Jones, D. Lean_Thinking; Simon \& Schuster: New York, NY, USA, 1996; ISBN 9780743231640.

20. Leong, W.D.; Lam, H.L.; Ng, W.P.Q.; Lim, C.H.; Tan, C.P.; Ponnambalam, S.G. Lean and green manufacturing-A review on its applications and impacts. Process. Integr. Optim. Sustain. 2019, 3, 5-23. [CrossRef]

21. John, L.; Sampayo, M.; Peças, P. Lean \& Green on Industry 4.0 Context-Contribution to Understand L\&G Drivers and Design Principles. Int. J. Math. Eng. Manag. Sci. 2021, 6, 1214-1229.

22. Abualfaraa, W.; Salonitis, K.; Al-Ashaab, A.; Ala'raj, M. Lean-green manufacturing practices and their link with sustainability: A critical review. Sustainability 2020, 12, 981. [CrossRef]

23. Netland, T.; Powell, D. The Routledge Companion to Lean Management; Routledge: New York, NY, USA, 2016 ; ISBN 1138920592.

24. Pawlik, E.; Ijomah, W.; Corney, J. Lean remanufacturing. In The Routledge Companion to Lean Management; Netland, T., Powell, D.J., Eds.; Routledge: New York, NY, USA, 2016; p. 179. ISBN 9781317416517.

25. Amezquita, T.; Bras, B. Lean remanufacture of an automobile clutch. In Proceedings of the 1st International Working Seminar on Reuse, Eindhoven, The Netherlands, 11-13 November 1996.

26. Fargher, J.S.W., Jr. Lean Manufacturing and Remanufacturing Implementation Tools; University of Missouri: Rolla, MO, USA, 2007.

27. Pawlik, E.; Ijomah, W.; Corney, J. Current state and future perspective research on lean remanufacturing-Focusing on the automotive industry. In Advances in Production Management Systems. Competitive Manufacturing for Innovative Products and Services, IFIP Advances in Information and Communication Technology; Emmanouilidis, C., Taisch, M., Kiritsis, D., Eds.; Springer: Berlin/Heidelberg, Germany, 2013; Volume 397, pp. 429-436; ISBN 978-3-642-40351-4.

28. Sundin, E. How can remanufacturing processes become leaner. In Proceedings of the 13th CIRP Intl Conference on Life Cycle Engineering, Leuven, Belgium, 31 May-2 June 2006.

29. Kanikuła, T.; Koch, T. Methodology of designing disassembly and reassembly processes using lean thinking approach. In Proceedings of the IFIP International Conference on Advances in Production Management Systems 2009, Bordeaux, France, 21-23 September 2009; Vallespir, B., Alix, T., Eds.; Springer: Berlin/Heidelberg, Germany, 2010.

30. Kurilova-Palisaitiene, J.; Sundin, E. Toward pull remanufacturing: A case study on material and information flow uncertainties at a German engine remanufacturer. Procedia CIRP 2015, 26, 270-275. [CrossRef]

31. Hunter, S.L.; Black, J.T. Lean Remanufacturing: A Cellular Case Study. J. Adv. Manuf. Syst. 2007, 6, 129-144. [CrossRef]

32. Ostlin, J.; Ekholm, H. Lean production principles in remanufacturing: A case study at a toner cartridge remanufacturer. In Electronics \& the Environment, Proceedings of the 2007 IEEE International Symposium on Electronics and the Environment, Orlando, FL, USA, 7-10 May 2007; IEEE: New York, NY, USA, 2007; pp. 216-221. 
33. Ostrowski, D.; Jagodziński, J. Operation of an employee suggestion system in administration and production departments of a remanufacturing company. J. Remanuf. 2021, 11, 107-120. [CrossRef]

34. Pascual, J.A.; Pimentel, C.; Mateo, M.; Hoyuelos, I.; Matias, J.; Gento, A.M. A learning factory for remanufacturing: A new configuration. In Proceedings of the 6th European Lean Educator Conference, Milan, Italy, 11-13 November 2019; Rossi, M., Rossini, M., Terzi, S., Eds.; Springer: Cham, Switzerland, 2020; pp. 1-10.

35. Voss, C. Case research in operations management. In Researching Operations Management; Routledge: Oxford, UK, 2010; pp. 176-209.

36. Scandura, T.A.; Williams, E.A. Research methodology in management: Current practices, trends, and implications for future research. Acad. Manag. J. 2000. [CrossRef]

37. Eisenhardt, K.M. Building Theories from Case Study Research. Acad. Manag. Rev. 1989, 14, 532-550. [CrossRef]

38. Obara, S.; Wilburn, D. Toyota by Toyota: Reflections from the Inside Leaders on the Techniques That Revolutionized the Industry; CRC Press: Boca Raton, FL, USA, 2012.

39. Kurilova-Palisaitiene, J.; Sundin, E.; Poksinska, B. Remanufacturing challenges and possible lean improvements. J. Clean. Prod. 2018, 172, 3225-3236. [CrossRef]

40. Ballé, M.; Chartier, N.; Coignet, P.; Olivencia, S. The Lean Sensei; Lean Enterprise Institute: Boston, MA, USA, 2019; ISBN 9781934109571. 